community "could be a very delicate issue" the agency's director and the principal sponsor of the centre, Lt Gen. William Hilsman, said in a recent interview, stating that the schools had been chosen because they were less likely than universities to view the military interest in education as a threat to academic freedom.

Meanwhile the universities themselves are hoping to receive some guidance from a report recently completed by the Defense Science Board for the Department of Defense. The report is expected to recommend the development of clear guidelines to separate basic research from that which may be of a more practical nature and hence require special protection and treatment.

David Dickson

\section{British university crisis Cuts with tears}

British universities, still in chaos over how to meet cuts in government income over the next three years, were relieved last week to learn that they are to be compensated for payments made to academics who must lose their jobs. A letter from the University Grants Committee set out the terms under which they will be reimbursed for payments made to redundant staff. Essentially, the compensation scheme is that devised by the Committee of ViceChancellors and Principals and blessed by the Secretary of State for Education and Science a week earlier.

The approved scheme allows redundant academic staff below 50 years of age to claim one month's pay for each year of service plus one month's pay for every year of service in excess of five years or after their 30th birthday, whichever is the later. Staff over 50 will be entitled to compensation under the universities' scheme for premature retirement introduced a year ago. The grants committee says that it will not meet claims for compensation that are more generous than those now approved, which begs the question of who will pay if the courts decide that higher awards are just.

The universities' relief will also be tempered by other provisos spelled out in the committee's letter. Full reimbursement will be made only where universities convince the grants committee that redundancies are made in the interests of

\section{Correction}

In the note in News and Views by $\mathrm{Dr}$ R.J. Wilson in last week's Nature (4 February, page 369), the third paragraph should, except for a misunderstanding in the Nature office, have referred to the work of Professor David Weatherall and his colleagues in the Nuffield Department of Clinical Medicine at the University of Oxford; the article describing this work will be published in Nature shortly. economy and that resulting vacancies will not be refilled. Redundancies should also be "consistent with academic planning", a vague phrase thought to give the committee some come-back if universities fail to comply with its advice on general policy.

In the meantime, the end of January deadline by which all universities were to have submitted outlines of how they plan to adapt has passed. Most have sent the numbers of staff they plan to lose by the end of the next academic year, on which basis the grants committee will allocate the $\mathfrak{1 7 0}$ million already set aside for helping with restructuring. It seems to be accepted that the sum will be inadequate to settle all claims, although the grants committee has not yet totted up those so far submitted. It is hoped, however, that the government will make more money available by the beginning of the following year.

Only about half the universities have managed to submit returns on how they plan to restructure operations. The grants committee will be looking at the returns later this month, when it will decide whether to reallocate money to those universities that have asked to be reconsidered. The committee is unwilling to say whether the returns suggest that the universities are following its advice, except that one or two of them look "a bit odd".

Some universities seem to have managed to get away with fewer compulsory redundancies than was originally expected. The University of Leicester, for example, plans to make none. The Association of University Teachers claims that success in minimizing compulsory redundancies may reflect the efforts of its members in putting forward alternative strategies for coping with the cuts.

Judy Redfearn

\section{Soviet dissidents Helpers divided}

Scientists campagning for academic freedom and civil and human rights for their less fortunate colleagues cannot confine themselves to a single cause or campaign. This was the consensus of opinion at a one-day seminar at University College, Oxford, on 7 February, organized by the Scientific and Medical Committee for Soviet Jewry.

The main guest was Dr Mark Azbel, from the University of Tel Aviv, himself a former refusnik and convenor of the Moscow Sunday Scientific Seminars for Refusniks, Dar Azbel, like most Soviet Jewish activists believes that a clear distinction should be made between the Jewish emigration movement and the dissident movement in the USSR. Any confusion between the Jews, whose only wish is to leave the Soviet Union, and the dissidents who would prefer to stay there and reform the system from within, is, he believes, dangerous to both movements, allowing the Soviet authorities to accuse the Jews of subversion and dissidents of

\section{Small growth fund}

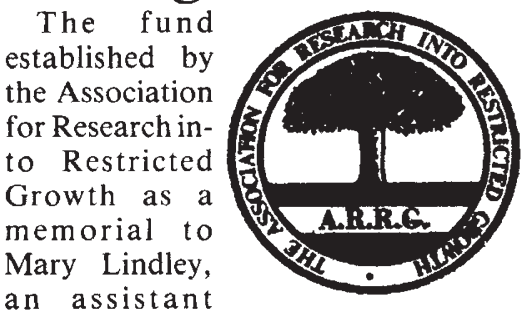

editor of Nature who died in May 1981, has now reached $£ 700$. The group intends to use the money to help young people suffering from restricted growth in problems arising during their early education. Further donations should be sent to the Treasurer, Pam Worsfold, 8 Cotswold Avenue, Chelmsford, Essex.

being agents of international Zionism.

The other participants, however, felt obliged to disagree with him. Professor Paul Kessler from the Collège de France, who spoke on "Visiting Refusniks in the Soviet Union", said that he could not in conscience, while on a vist to Moscow, visit refusniks and refuse to visit dissident scientists who had also, though for other reasons, been expelled from their jobs. Dr Louis Cohen, executive secretary of the Institute of Physics, speaking on "Transnational science as an influence on Soviet science policy", talked not only of the work of his own institute which in 1978 had sponsored the parallel trial in defence of Dr Yurii Orlov, but also the valuable work of the American Association for the Advancement of Science, primarily on behalf of victims of oppression in South America and also for other human rights causes, including the refusniks. Dr Gary Low Beer, who is both head of the Scientific and Medical Committee for Soviet Jewry, and a prominent campaigner against the political misuse of psychiatry, put the point bluntly and pragmatically. One cannot expect one's colleagues to campaign for a human rights cause in which one feels a special interest, if one is unwilling to reciprocate for the causes they favour.

In reply, Dr Azbel explained that he did not want to discourage scientists who wished to campaign for dissidents. Everyone, he said, must choose his own cause. But it was better to campaign for only one person at a time, rather than several in parallel.

His support of this line of action seemed inspired not only by practical considerations but by the Yiddish proverb that to save one life is equivalent to saving all humanity. The seminar particpants, however, applauded him warmly, but clearly still favoured a unified stand by the scientific community as a whole, on all abuses of human rights and academic freedom, wherever they occur.

Vera Rich 